\title{
The task of urban black public theology
}

\begin{abstract}
Author:
Vuyani S. Vellem ${ }^{1}$

Affiliation:

${ }^{1}$ Department of Dogmatics and Christian Ethics, Faculty of Theology, University of Pretoria, South Africa

\section{Note:}

This article forms part of the special collection on 'Doing urban public theology in South Africa: Visions, approaches, themes and practices towards a new agenda' in HTS Teologiese Studies/Theological Studies Volume 70, Issue 3, 2014. The collection is the result of the project 'Urban Public Theology', which was initiated by the Institute for Urban Ministry but later expanded to include several academic departments and institutes at the University of Pretoria (UP) and University of South Africa (UNISA).

The leading centres in this regard were the Centre for Contextual Ministry (UP) and the Research Institute for Theology and Religion (UNISA).
\end{abstract}

\section{Correspondence to:}

Vuyani Vellem

Email:

vuyani.vellem@up.ac.za

Postal address:

Private Bag X20, Hatfield

0028, Pretoria, South Africa

\section{Dates:}

Received: 16 May 2014

Accepted: 08 July 2014

Published: 20 Nov. 2014

Read online:
Twenty years after the demise of apartheid, a typical South African city remains bifurcated. The mushrooming of squatter camps, mekhukhu, in our big cities, symptomises a history that defined the majority of South Africans as sojourners and vagabonds in their motherland. Destined to die in the rural reserves after the extraction of their labour and confined to 'locations' in-between the 'city' and the rural 'home', black experience in the post-1994 city continues to be a manifestation of a life disintegrated from an integrated vision of ikhaya (oikos) - household - and urban life in democratic South Africa. By critiquing the policies of the post1994 government on urbanisation, the article argues that for inclusion in the city, the colonial and apartheid polis is not adequate redress to the black experience of urbanisation in South Africa. The quest for the transformation of a city in order for an integrated city in the post-1994 South Africa to be achieved is ostensibly the best starting point, this article argues.

\section{Introduction}

The main purpose of this article is to critique the vision for urbanisation in post-1994 South Africa. This critique is conducted within the context of un-reconciled policy principles of urbanisation that ultimately subjugate the movement of the poor to development policies without dealing with urbanisation itself as a reality. Urbanisation in South Africa is fraught with slavery, cheap and docile labour, and racism, all theologised to alienate black Africans from their land. There is a sense at theoretical level that the metaphysics of urbanisation become important for black critical engagement. The article elects the township experience as the interlocutor of urban black public theology and concludes with a brief and tentative suggestion of what its task could be in post-1994 South Africa.

\section{Context}

This article reflects on the challenges of urbanisation in the context of the post-1994 South Africa. Whilst these challenges have a long history which will be briefly presented below, the pertinent contextual question is whether the current government succeeds to respond to an old problem of urbanisation through its relevant policies, or not. This is an important question if one assumes that apartheid artificially throttled urbanisation on racial grounds. Equally important is the need to take into account the new challenges which impact on the struggles of black African people and their movement in their country of birth. One of the impressions I have developed since living in Johannesburg for the past 10 years emanates from my constant visits to Park Station, and particularly during holidays or 'busy' times every year. I have times like Good Friday and Easter or December holidays in mind: crowds, congestion, stampedes, long queues, people sleeping on the floor, children - in one isiXhosa word, isiphithiphithi - roughly meaning chaos! One day after having collected my brother from Park Station during one of the 'seasons' of stampede, I harboured deep feelings of resentment. I thought: One sign of the success of our political liberation will be a less chaotic Park Station. I have also been at OR Tambo Airport during these hectic periods, but the situation is different!

Nevhutanda (2007:462) argues that transport is very important in relation to urbanisation. More importantly, he argues, few resources for the management of growth in cities lead to over-population and a lower quality of infrastructure. He takes issue with the shortcomings of transport policy and failure to adequately implement existing transport policy in post-1994 South Africa. Although he uncritically discusses the relationship between models of transport and the globalising world - the influence of trans-national cooperatives, or the Washington Consensus and city life in this century - one should concur that there is a link between policies of transport and urbanisation. In addition, it is important in the discussion of urbanisation to consider the hegemony of economic management in the 21st century.

How to cite this article: Vellem, V.S., 2014, 'The task of urban black public theology', HTS Teologiese Studies/Theological Studies 70(3), Art. \#2728, 6 pages. http://dx.doi.org/10.4102/hts.v70i3.2728

Copyright: @ 2014. The Authors. Licensee: AOSIS OpenJournals. This work is licensed under the Creative Commons Attribution License. 
The current problems with e-tolling and the Gautrain are examples of a skewed vision of urbanisation in post-1994 South Africa. Whilst there is, and has been for many years, a poor transport infrastructure for the poor the choices in the improvement of transport made by the government in post-1994 South Africa are simply appalling. Even more disturbing is the picture that Doreen Atkinson and Lochner Marais (2006) present in their review of the policies of the African National Congress-led government on urbanisation from 1994 to 2002. They discern diverse and un-reconciled policy principles that have shaped the urbanisation discourse in post-1994 South Africa. They argue that even the Reconstruction and Development Programme (RDP) document is vague on urbanisation although it recognised the spatial structure that apartheid bequeathed to South Africa. Whilst the new democratic government has rightly chosen to focus on poverty, it has unfortunately relegated issues of space and thus urbanisation as secondary to policy-making. In this context, what can Black Theology of liberation contribute to urbanisation in South Africa? But first, what is urbanisation?

\section{Urbanisation: What is it?}

Urbanisation is a fascinating concept that is defined in different ways. It is, therefore, important to at least describe how it is understood for purposes of this article. One is inclined to go along with an explanation of urbanisation as a process that entails a movement of people into cities (Henslin 1995:569). The movement of people from rural contexts to the cities is related to the creation of cities if one understands a city as 'a place in which a large number of people are permanently based and do not produce their own food' (Henslin 1995:568). There are two important phenomena that must be observed at this juncture: the movement of people, and large numbers of people living in one place, but not producing their own food. In other words, by its very nature, a city displaces certain functions when it is formed and in this definition by Henslin, the displacement of food production is an example. There are reasons to find this definition helpful. For example, as a phenomenon of a city that is conceptualised as a space of integrated economy, and as a site of social and political identity and indeed a space of conflict and innovation at the same time (Parker 2004:4), the idea of displacement of food symbolically attains profound significance. Simon Parker further identifies what he calls four Cs that define urban theory: culture, consumption, conflict and community (2004:4). Following the criticality of food in critical theory and indeed Marx's own view about the importance of food in the history of production, the displacement of food as one feature of urbanisation should be understood both literally and symbolically in the discussion in this article.

Food in the black African prototype of home, ikhaya, aggregates the economy, politics, identity and the imaginary of a home and is viewed in this description of urbanisation as an important category that remains an antithesis to urban commodification of space. The displacement of food thus implies the displacement of life in its integrated form as a feature that our conversation seeks to underscore: the 'reification of the urban' (Susser 2002:3). The position held in this article is that it is not the displacement of only food production that should define city formation, particularly in respect of the formation and history of the South African city. Castells's rendition superbly embraces this view:

The term urbanization refers both to the constitution of specific spatial forms of human societies characterised by the significant concentration of activities and populations in a limited space and to the existence and diffusion of a particular cultural system, the urban culture. (Susser 2002:28)

Following this, displacement of food signifies the displacement of black African cultural systems which are important for economic, political, aesthetical and religious imaginary in limited spaces of urban culture in South Africa. This point will be returned to, but, for now, the movement of large numbers of people to city life which displaces certain functions of production is adequate to paint a picture of what constitutes the conversation in this article.

The development of cities and thus the movement of people to cities goes far back in human history. Logically, it must be conceded that in Africa, and in South Africa, there was a movement of people even before the discovery of gold (Mabin 1992). Of course, there were few cities with large numbers of people until the Industrial Revolution in the West. The Industrial Revolution brought about a different way of human production as it became a distinct era of mechanical means of transportation and communication, thus enhancing greater movement of people and products than before. It is not necessary to spend time to discuss how this development has led to cities becoming bigger in the 20th century resulting in what is now metropoles and megapoles. With the massive movement of people to the cities and its impact on the levels of production by these people, the Industrial Revolution was a significant catalyst when the globalisation during this century is considered. Today the largest cities in the world have population numbers close to 20 million: Istanbul in Turkey, Cairo in Egypt and Lagos in Nigeria are examples, to name a few.

With this kind of growth in the size of cities and the corresponding movement of people in huge numbers into city life, there is a strong inclination that urbanisation is not going to stop: it is continuing by the meteoric rise of technology and the communication revolution that characterises the 21st century. The improvement of technology and the means of transport imply, amongst others, an inevitable growth of cities and the movement of people. This process is not without challenges and problems, as it certainly implies the displacement of food production and other human needs from huge numbers of people.

Scholars of urbanisation therefore argue in different ways about the need for appropriating philosophical approaches to the management of urbanisation (Dewar 1992; Parker 2004; Susser 2002). Some of the challenges that Henslin identifies include alienation of human beings from one another. City 
life brings about characteristics of a society described as Gesellschaft, 'secondary, impersonal relationships' (Henslin 1995:576). Furthermore, Henslin argues, communal relationships in city life become seriously challenged and this does not do any justice to the experience of the city. Dewar argues that focusing on the efficiency of utility services in urban management does not help to deal with what he defines as the current urban structure that is against life. With the South African situation specifically in mind, Dewar (1992) says:

There are currently no cohesive ideas about the form of city South Africa should be moving towards. The urban problem is interpreted almost entirely as the provision of shelter: as a consequence, kilometres of housing areas are emerging but few qualities or advantages of 'city'. The emerging urban structure and form is exploitative. It does not facilitate life: it massively retards it. It does not help people to improve their material wellbeing: it makes them poor. It is not sympathetic to nature: it destroys (pp. 253-254)

The major aim of this section is to provide a broad view of what urbanisation is all about. This concept implies a phenomenon that is tens of thousands of years old. It entails the movement of people, coming together to form a city in search of better opportunities, but by doing so displacing certain aspects that are essential for life, such as own production of food. Changes in history, particularly the modes of production, such as the Industrial Revolution, exacerbated this movement and ipso facto the growth of the city itself. The massive scale of this movement by the people and the subsequent complexities of life in the city resulting from the huge growth of the city itself, have had a bearing on the experience of city life. Alienation and impaired communal relations of life are amongst some of the challenges that go along with urbanisation: but the sentiments by Dewar expressed above are much more telling.

There are advantages to city life that are lost in the disintegrated focus of city growth and management. In its current form, urbanisation in South Africa is against life: it is a reason for impoverishment and destroys life, Dewar says (1992:245). These views were expressed roughly 20 years ago. Twenty years later, in the light of my conversations with the Thabo Mbeki community, very little change seems to have taken place. Let us now turn to a brief elaboration of the history of urbanisation in South Africa.

\section{Urbanisation in South Africa}

I do not wish to repeat the South African history of urbanisation, but rather the picture of what I presume to be pertinent for our discussion. There are already important insights on this subject. Mabin (1992) for example attributes the discovery of gold and the resultant economic expansion as the main factor behind the urbanisation process in South Africa. David Smith (1992:1) also makes an important point when he says that urbanisation perhaps undermined apartheid as it defied the limitations imposed on the movement by black Africans. It is nonetheless important to note that urbanisation in South Africa is difficult to comprehend without cheap labour. In South Africa, the migrant labour system entailed an intense system of recruiting cheap black labour from the rural areas when gold and diamonds were discovered.

It should be remembered that 5 years after Van Riebeeck's arrival in the Cape, the project of building a half-way station between Holland and India was concluded. Following this, a decision for some in Van Riebeeck's company to settle in South Africa was made. This decision also meant that experimentation on farming had to commence (Boeseken 1977), which resulted in the importation of slaves in the 1690s. Slavery is, therefore, one of the historical facts that defined work between white and black in South Africa even before the discovery of gold. There were also theological views at that time, what the missionaries called the 'Gospel of Work.' In The Christian Express of 01 August 1878 we find the following sentiments about the 'Gospel of Work':

We want to see natives become workers. And we believe Christianity will be a chief cause of their becoming working people. How this must come to be is twofold. Christianity creates needs. Generally speaking, everyman will work just as much as he requires to do more. There will be a constant relation between a time a man works and his necessities ... If you want men to work, then, you must get them to need. Create need and you supply stimulus to work, you enlist the workers own will on the side of labour. Few men anywhere, and certainly no heathen men, ever work for the mere pleasure of working. Now, the speediest way of creating needs among these peoples is to Christianize them. (The Christian Express 1878:1-2) ${ }^{1}$

If race indeed became a distinguishing factor between slave and slave-master then the Gospel of Work was the theological content of this racial character of work. 'Natives' had to become workers by being Christianised. Of course the sentiments above are not directly related to the era of Jan Van Riebeeck, but to the context of the British colonialism of South Africa. The point intended is illustrative. The refreshment station evokes slavery and racism, whilst the British colony baptises 'native' work through Christianity. The main point is that all this describes a situation before the discovery of gold and diamonds in South Africa.

To reiterate the point already made, it is important to remember that Africa had its own urban culture long before the arrival of colonialists. There were cities along the Nile, and in the highlands of Ethiopia and Timbuktu. Ife, in what is now southwest Nigeria, is believed to be the city where the origins of humanity in Yoruba traditions can be traced to. The arrival of colonialists and Christianity nonetheless changed the culture of city-making. Gugler (1999) says:

Luanda had been founded by the Portuguese in 1575 and became the administrative centre of Angola in 1627. Cape Town had been established by the Dutch in 1652 as a supply station on the Dutch East India Company's sea-route to the East. To settle freed slaves the British founded Freetown in 1792, the Americans Monrovia in 1822, and the French Libreville in 1848. Dakar grew up around a French port built in 1861. In 1881 Kinshasa was renamed Leopoldville after the king of the Belgians (p. 219)

1.See Villa-Vicencio's longer version of this quotation in his chapter that deals with 'Imperialists and Missionaries' (Villa-Vicencio 1988:44-45). 
The arrival of the colonial powers with Christian missionaries changed the culture of urbanisation that existed before. And the discovery of gold and diamonds in Kimberley, Johannesburg, and minerals in Kitwe, Askum and Dakar changed the face of the continent for many years to come. Railway construction from Cape Town, Port Elizabeth and Kimberley in South Africa and from Beira to the Zambian copper belt and across to Lubumbashi had an impact on the face of the continent in the 19th century. More importantly, the culture of urbanisation as the movement of people and the formation of cities was a mixture of slavery, cheap labour, racism and Christianity, with some benefiting; whilst others became the victims.

According to Sampie Terreblanche the British capitalist and the Afrikaner farmer united against black Africans for cheap labour when diamonds and gold were discovered. What is even more pertinent is what he says about urbanisation:

Concerned about the threat of urbanisation, the Smuts government passed the Native (Urban Areas) Act in 1923. It was based on the following dictum enshrined in the 1921 Transvaal Local Government Commission, chaired by Colonel Frederick Stallard: 'The Native should only be allowed to enter urban areas, which are essentially the white man's creation, when he is willing to minister to the needs of the white man, and should depart therefore when he ceases to minister.' For several decades, the Urban Areas Act - based on 'Stallardism' - was the main vehicle for administering 'influx control' and urbanisation. (Terreblanche 2002:255)

Terreblanche argues that economic and capitalist imperatives were behind segregation and therefore the racist ideologies that became rampant and repugnant in our South African history.

What is more significant to grasp is the extent to which racism and economics combined to throttle the movement of black Africans and thus the character of urbanisation in South Africa as a racist, capitalist agenda to this day. Before the discovery of gold and diamonds, black Africans were generally believed to be content with their lives where they were (Bundy 1988; Worden 1988). Black Africans were successful farmers, cultivating their land assiduously. They had to be coerced into the mining and agricultural sectors to supply cheap labour through a number of laws that were passed: tax, location and vagrancy laws to mention but a few. Terreblanche (2002) argues that a distinction needs to be made between practices that were divisive:

$[A]$ nd legislation as methods of labour repression aimed at guaranteeing an adequate supply of cheap black labour on the one hand, and those as methods of labour discrimination aimed at protecting white labour against competition from already cheap and docile black labour on the other. (p. 253)

Yet urbanisation became throttled and controlled!

The apartheid regime took a strong Stallardist approach against the views advocated for the relaxation of this approach that was assumed by British colonialists. Around the elections in 1948:

[T] he NP regarded growing African urbanisation with horror, and presented it as a diabolical formula for the 'swamping' of white civilization. The NP's persistent beating of the 'swart gevaar' ('black peril') drum probably played a decisive role in its victory. (Terreblanche 2002:314)

The point is that urbanisation, whilst plainly viewed as an inevitable process of people's movement to cities (places inhabited by human beings who do not produce food for themselves), in South Africa this movement and the construction of the apartheid city cannot be viewed without racial, political, economic and theological views that saw the movement of black Africans only as the means of cheap and docile labour.

One can only agree with David Smith (1992:316) when he concluded some time ago that the structure of the apartheid city is still around even after the demise of apartheid. Smith correctly argues that it is the peri-urban shack that seems to have changed the apartheid city. Indeed, for the past 20 years of South Africa's democracy, one has seen a proliferation of squatter camps particularly in the major cities that constituted the hierarchy of cities formed during the apartheid era. There is something happening on the periphery of major cities in our post-1994 South Africa, countenanced by a forest of mekhukhu (Vellem 2010). In Durban, in the 1990s, at a place called Amawoti, a dense 'jungle' of mekhukhu, continues to be a subject of discussion. At present it is Abahlali basemjondolo - the South African Shackdwellers Movement - that has irrupted as a space of contest for life. In Cape Town, along the N2, you will see shacks. Diepsloot in Johannesburg and Thabo Mbeki Village along the Malibongwe Drive, and many others, are signs of the distortions of city-making and urbanisation in post-1994 South Africa. Where do we then locate our interlocution for urban black public theology?

\section{'Kassie'3: A site of urban black public theology}

Frantz Fanon said:

True liberation is not pseudo-independence in which ministers having a limited responsibility hobnob with an economy dominated by the colonial pact. Liberation is the total destruction of the colonial system, from the pre-eminence of the language of the oppressor and 'departmentalization', to the customs union that in reality maintains former colonized in the meshes of the culture, of the fashion, and of the images of the colonialist. (Gibson 2011:116)

It is argued that the township is the place of liberation and the total destruction of the colonial system and its culture. What might be a picture of what city life is on the periurban settlements in post-1994 South Africa is the Thabo Mbeki village?

3.'Kassie' from Afrikaans "lokasie'. 
On 12 December 2012, in one of the sessions ${ }^{4}$ we had with about 50 people of the community of Thabo Mbeki village, one of the most fascinating, thought-provoking conversations ensued after discussing the following two sensitive questions that inspired our dialogue: 'Why are you living here at Thabo Mbeki village?' and 'Why did you leave your home which at least had land in the rural areas and which in the past was used to produce food whilst you are mostly unemployed and landless here at Thabo Mbeki?' One of the interlocutors responded by asking me a similar question: 'Why are you living here in Johannesburg?' She went further: 'Johannesburg is not your home as much as it is not our home, and everyone who came to Johannesburg is in search of good life!' These questions ignited a heated conversation.

One participant in the conversation, Abraham Nthite, explained that many people living in Thabo Mbeki village were victims of an eviction that took place in 2004. They received letters delivered to them by the sheriff instructing them to move out of their original places of residence. Initially, Abraham continued, they were promised a better residential place as an alternative. The name Thabo Mbeki - for the land on which the community squatted - was suggested by the late Mike Makhumbuza as the evictions took place during the tenure of former President Thabo Mbeki in office. There were contradicting views about the official existence of this community and the name itself. Apparently, such a community needs to be officially declared by the municipality before they could receive proper services: if not, what they would be entitled to are ad hoc services. Therefore, in effect, the name is neither official nor is the community itself, despite the fact that it is de facto what the community calls itself and where they live. Another participant, Sara Ravhele, said that it was hard and painful for people to access areas where their ancestors were buried. Most of the surrounding places are white-owned and dogs and electric fences are used to deter those who might need to go and visit their ancestors where they are laid to rest. Mamodise Mokhine said she did not have any other place or home from where they were evicted: that place was her home. Thabo Mbeki was the only place for her to live now.

There are many voices that can help clarify the complex questions that are related to the main question of the conversation. Let us, therefore, return to the question posed to the community to conclude this Thabo Mbeki exercise for the purpose of this article. The community members said they could not go back to their 'rural' homes because there was too much poverty there. Some of them said they were still supported by their parents and could not go 'home' to bother them despite their lack of employment in Johannesburg. Johannesburg is where gold is, they argued. It is not only the rural communities in South Africa that are flocking to Johannesburg, but all races and even people from other countries are heading to Johannesburg in search of 'gold.' In a democratic South Africa, people are free to live where

4.In the work that I conducted, I had a team that was made up of community members. Mr Vuyani Pule was specifically my research assistant. He is the president
menter members. Mr Vuyani Pule was specifically my research assistant.
of the South African Council of Churches' (SACC) Youth Forum. they want, another voice said. My purpose here should be clear. The squalor and sordid condition of a squatter camp, mokhkhu, in post-1994 South Africa is a living experience of death in relation to urbanisation. Let us move to the black township to enrich the conversation.

Black people were not allowed to live in cities, yet they were forced to go to cities as cheap and docile labour. One of the most glaring testimonies of this reality is the township, a place between the rural and the urban spaces. Congestion, squalor, hygiene, sanitation, violence, crime and so on, are the features of townships in South Africa. In 1887 an idea was mooted to create locations at a convenient distance from the city to accommodate blacks. Major cities in South Africa followed this route. These locations had to be separated from whites because, amongst other concerns, white people feared the spread of contagious diseases. At the instance of the Lagden Commission of 1903-1905, the establishment of locations became a policy followed in the Reef mines. The word 'location' has persisted up to this day: lekeishene (Sesotho), ilokishi (isiXhosa) and the famous designation, kassie, from Afrikaans lokasie. In one letter written by the town clerk of East London it is said:

The benefits accruing to the town from the establishment of the location are that we compel natives to leave the town and be in the location at a certain hour, thereby preventing a lot of undesirable characters being about the streets. The chief point, however, is that it is undesirable to have natives living in the town, their presence leads to the accumulation of filth and generation of disease, besides being in other respects a great nuisance to the white population. (Reader 1961:13)

The building of 'match boxes' in many of our South African townships was essentially a response to the health hazards that were experienced around the 1900s. There was a Tuberculosis (TB) Commission which reported that locations were poised to spread the disease throughout the country: indeed, in 1918 there was a bad influenza epidemic. For years the locations were seen as breeding grounds for diseases in the white cities. This led, for the first time, to the different schemes for black African housing in South Africa. One of the worst nightmares in the townships in South Africa was the introduction of what was called the 'Durban model.' This was a system that entailed the building of beer-halls in the township, allegedly for revenue and improvement. What was worse was that the revenue accrued from these beer houses subsidised low rates for white residents in the city.

The progressive worsening of conditions, want of water, lack of road maintenance and electricity and increasing plot densities speak louder than words even in post-1994 South Africa. This is the essence of what township life is. It is land commodified, a space of contradictions created by colonialism and apartheid which must be transformed by our democratic government. The resilient struggles of black Africans who live in the township, ekassie, is our important question. One of the characteristics of township life is its bifurcated state (Mamdani 2001). If one looks at the civil space that was racialised under the colonial and 
apartheid administrations, it should be clear that race played an important part in urbanisation. On the other hand, the tribalised native administrations based on customary law, exemplified in the Bantustan administration and referred to as 'tribal cocoons called "homelands"' by Biko (2004:94) was forced on black Africans. Clearly locations were in a limbo between two spaces: the civil space of the whites and the tribal cocoons of white indirect control.

Locations were dumping grounds for black Africans not needed in the city but far away from 'home.' Whilst those who lived in the township were racially excluded from civic life in the city, they still were not at 'home' under the rule of customary law. The metamorphosed township life found expression in Tsotsi-taal, a township language that is a mixture of Afrikaans, isiZulu and other bits of African languages. The movement of the people in the township changed into one from ekassie to emakhaya, the homelands. Life in the township became dichotomised between those who lived ubulokishi, according to township style, and those who lived isintu, according to the African values. In brief, as in a limbo between two spaces, the 'city' and the fraudulent home, the 'homeland' - the township became a paradox: a quintessential contradiction of black African life that still remains in post-1994 South Africa. The life mutations that took place and which continue to take place in the township are either obnoxious or is a paradox. The vernacularisation ${ }^{5}$ and translation ${ }^{6}$ of city life into life-giving assets by black Africans in the township limbo is a site for the urbanisation models that could be uniquely South African and pro-life.

\section{Conclusion}

The task of urban black public theology is in the main to unmask urbanisation models that conceal the mixture of slavery, cheap labour and theologised distortions of human movement in South Africa and on the globe. Within the context of living death in mekhukhu and ekassie, black urban public theology must continue to search unabated for metamorphosed, home-made resources of language and symbols that the poor employ against alienating forces of urbanisation and the displacement of life-giving sources. Black urban public theology must critique the policies of urbanisation, particularly models influenced by the Washington Consensus which aim can only be to maintain isiphithiphiti - chaos - relegating others as sojourners and vagabonds in the land of their birth.

Urbanisation culture in South Africa must be unique and must open the movement of black Africans through transport liberated from race and exclusive economic

5.See the theory of vernacularisation by Lamin Sanneh (1989).

6.See the theory of the translatability of the gospel by Kwame Bediako. management. When one looks at the pseudo-religious distortions of the 21st century, particularly the military violence that supports the current and dominant form of economics, black African

culture must be affirmed against the reifying urban culture that historically combined racism, cheap and docile labour with theology to subdue millions of black South Africans. Indeed, as Kenneth (2001:132) Leech argues, urban theology as a discourse that 'antedates "contextual theology"' and 'local theology', will remain irrelevant if the oeuvre of urban black public theology is not embedded in the urban praxis of ekassie. One important sign will be improvements at Park Station.

\section{Acknowledgements Competing interests}

The author declares that he has no financial or personal relationship(s) that may have inappropriately influenced him in writing this article.

\section{References}

Atkinson, D. \& Marais, L., 2006, 'Urbanization and the future urban agenda in South Africa', in R. Tomlinson, U. Pillay \& J. du Toit (eds.), Democracy and delivery: Urban policy in South Africa, pp. 22-49, HSRC Press, Pretoria.

Bediako, K., 1995, Christianity in Africa: The renewal of a non-Western religion, Edinburgh University Press, Edinburgh, Scotland.

Biko, S., 2004, I write what I like, Picador, Johannesburg.

Boeseken, A.J., 1977, Slaves and free blacks in the Cape: 1658-1700, Tafelberg, Cape Town.

Bundy, C., 1988, The rise and fall of the South African peasantry, David Philip, Cape Town.

Dewar, D., 1992, 'Urbanization and the South African city,' in D. Smith (ed.), The apartheid city and beyond: Urbanization and social change in South Africa, pp. 243-254 Routledge, London.

Gibson, N., 2011, Fanonian practices in South Africa, UKZN Press, Scottsville.

Gugler, J., 1999, The urban transformation of the developing world, Oxford Press, Oxford.

Henslin, J.M., 1995, Sociology: A down to earth approach, 2nd edn., Allyn and Bacon, Boston.

Leech, K., 2001, Through our long exile, Darton, Longman \& Todd, London.

Mabin, A., 1992, 'Dispossesion, exploitation and struggle: An historical overview of South African urbanization', in D. Smith (ed.), The apartheid city and beyond:

Mamdani, M., 1996, Citizen and subject, David and Phillip, Cape Town.

Mamdani, M., 2001, 'Beyond settler and natives as political identities: Overcoming the political legacy of colonialism', Comparative Studies in Society and History 43(4), 651-664.

Nevhutanda, A., 2007, 'Impact of rapid urbanization of South African cities on their transport policies,' 26th Southern Transport Conference (SATC), Pretoria, South Africa, 09-12 July, 2007, pp. 457-465.

Parker, S., 2004, Urban theory and the urban experience: Encountering the city, Routledge, London.

Reader, D.H., 1961, The black man's portion: History, demography and living in the native locations of East London, Oxford University, Cape Town.

Sanneh, L. (ed.), 1989, Translating the message: The missionary impact on culture, Orbis Books, Maryknoll.

Smith, D., 1992, The apartheid city and beyond: Urbanization and social change in South Africa, Routledge, London.

Susser, I., 2002, The Castells reader on cities and social theory, Blackwell, Oxford.

Terreblanche, S.J., 2002, A history of inequality in South Africa, 1652-2002, University of Natal, Pietermaritzburg.

Vellem, V., 2010, 'Prophetic witness in black theology-with special reference to the Kairos document', HTS Teologiese Studies/Theological Studies 66(1), Art. \#800, 6 Kairos document', HTS Teologiese Studies/Theol
pages. http://dx.doi.org.10.4102/hts.v66i1.800

Villa-Vicencio, C., 1988, Trapped in apartheid, David Phillip, Cape Town.

Worden, N., 1998, The making of a city, David Philip, Cape Town. 